\title{
Building a Sustainable Energy Future, One Community at a Time
}

Sharon JW Klein ${ }^{a \star}$, Stephanie Coffey ${ }^{a}$

*corresponding author

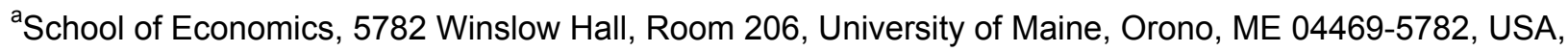
Phone: 1207581 3174, Fax: 1207581 4278, sharon.klein@maine.edu, stephanie.coffey@maine.edu

\section{ABSTRACT}

Solving energy issues requires integrated solutions at all societal and institutional levels. Community renewable energy and energy efficiency initiatives offer a complementary model for renewable energy deployment and have several advantages over the prevailing "top down" strategy employed in the US. In this paper, we present a review of the theoretical basis for community energy as a catalyst for energy behavior change; examine contrasting viewpoints of the definition of community energy; and review community energy literature. The first literature review compares energy behavior lessons from context independent individualistic and context dependent collective action theories. The review of community energy literature lists the energy option and geographical focus of more than 70 community energy studies from around the world and summarizes key lessons from this literature. In addition, we also present the data sources for a new US Community Energy Database that will be publicly available in the near future and introduce a new classification system for community renewable energy projects based on the results of this database. Finally, we present recommendations for future research in this rapidly growing field.

\section{KEYWORDS}

Community Energy; Renewable Energy; Sustainable Energy; Grassroots Innovation; Strategic Niche Management Theory; Multi-Level Perspective 


\section{Introduction ${ }^{1}$}

Solving energy issues requires integrated solutions at all societal and institutional levels. The dominant "top-down" paradigm of government incentives and/or regulations for sustainable energy supply and consumer behavior has led to significant reductions in environmental and public health impacts while maintaining a reliable and low-cost energy system [1]. Despite these important sustainability advances, the current energy system in the United States is: still responsible for nearly $20 \%$ of global greenhouse gas emissions, of which more than $70 \%$ come from the supply, distribution and use of energy for electricity, transportation, and heating [2]; linked to more than 20,000 premature deaths/year from accidents and air pollution [3]; and highly dependent on global energy markets for supply and pricing [4]. Current energy policy actions will have lasting impacts on human and ecological systems; thus, we must critically analyze alternatives to this top-down approach for encouraging citizen awareness and participation in a sustainable energy future.

"Community energy" is a growing movement in the US and around the world [5]. People are adopting sustainable energy technology and strategies (renewable energy, energy efficiency, conservation) in groups and/or on shared property, in contrast to traditional individualistic adoption. Many studies have been published in the last $10-15$ years to try to understand this growing movement. This article is the first to review these studies and to characterize the state of US community energy. This article advances community energy knowledge by answering the following research questions through a comprehensive review of published literature: What is the theoretical basis for community energy? What

\footnotetext{
${ }^{1}$ Abbreviations: Appalachian Institute for Renewable Energy, AIRE; benefit-cost analysis, BCA; Clean Energy Collective, CEC; community choice aggregation, CCA; community renewable energy, CRE; context-dependent collective, CDC; context-independent individualistic, CII; decision-maker, DM; Department of Energy, DOE; Environmental Protection Agency, EPA; Fellowship for Intentional Community, FIC; Florida Keys Electric Cooperative, FKEC; limited liability company, LLC; multi-level perspective, MLP; National Renewable Energy Laboratory, NREL; photovoltaic, PV; power purchase agreement, PPA; renewable energy and energy efficiency, RE3; special purpose entity, SPE; strategic and social niche management, SNM; transition towns, TT; Vermont Clean Action Network, VECAN
} 
is community energy? What are the different ways in which it is being implemented? And, specifically, what is the state of community energy in the US? In addition, this article presents a new classification system for community renewable energy projects in the US based on our new US Community Energy Database.

\section{What is the theoretical basis for community energy? A review of energy behavior change literature}

Recent definitions of sustainable energy emphasize the importance of meeting growing energy needs of both present and future generations while addressing social, environmental, economic and technological challenges [6-8]. Many technological solutions are commercially available to improve energy sustainability, including renewable energy (solar, wind, biomass, geothermal, water) and energy efficiency (RE3) options at residential, commercial, and industrial scales. These solutions were developed through engineering-economic methods, which focus on maximizing efficiency and minimizing cost. However, there is a significant gap between the variety of technological energy solutions currently available and actual RE3 adoption [9]. Technological lock-in and self-reinforcement perpetuate pathdependency [10] in the current energy system because consumers use energy without needing to understand how it is generated or the sustainability impacts associated with its use. Traditional energy behavior "interventions" in the US (i.e., regulations, policies, programs, measures, activities, or events that aim to influence behavior [9]) focus on individual choices operating in isolation. These interventions are grounded in context-independent individualistic (CII) theories and approaches that often do not incorporate behaviors of other individuals or social groups in individual decision-making [9,11]). Although Cll approaches offer important lessons for encouraging individual RE3 adoption, further evidence suggests a context-dependent approach, which considers collective action (CDC) and the complex relationships among individuals, technological information, and social institutions, may help CII approaches in advancing widespread RE3 diffusion [9,11-15]. This evidence is supported by a long history of grassroots social movements effecting national and global change in the areas of human rights \& environmental protection [16] as well as RE3 technology development and adoption [17]. 


\subsection{Context-independent individualistic literature}

Engineering and neoclassical economics create choice models and techno-economic assessments based on utility, rational choice, and standard preference theories to capture the lifetime costs per unit technical performance of a given energy decision, often culminating in values of dollars per unit energy, cost-effectiveness ratios, or net present value estimates through widely used approaches like benefit-cost analysis (BCA). These approaches are useful in that they merge complex technical information with spending and revenue at different time scales, yielding a concise representative value [12]. This benefit is reflected in the fact that BCA is a required approach for all US federal government agencies in justifying new rules [18]. However, traditional BCA and similar approaches are based on a set of simplifying assumptions about the decision-maker (DM), including: 1) the DM is rational and consciously seeks to maximize his/her own utility (i.e., well-being, often represented as personal wealth); 2) the DM consistently prefers benefits that occur in the present rather than future (represented by a constant discount rate); 3) the DM is autonomous, but affected by some limited factors; 4) decisions are independent of other individuals or social institutions; 5) DM preferences are well-defined, fixed, and consistent [9].

The Information Deficit Model, based in environmental \& social psychology, follows this logic in explaining why rational autonomous DMs do not take environmental action: they do not have enough information [19]. Theories of Planned Behavior, Altruism, Empathy, and Prosocial Behavior evolved in response to empirical evidence that the Information Deficit Model did not represent actual behavior, revealing that personal attitudes, values and beliefs also strongly affect behavior [19]. These theories advance the importance of incorporating considerations of social normative pressures (norms) in strategies to change DM behavior, while maintaining assumptions consistent with utility and rational choice theory [9]. Cognitive psychology and behavioral economics relax the rational behavior assumption by introducing the concept of "bounded rationality" along with Appraisal and Prospect theories, which explain that decisions and behaviors often arise from a set of complex \& often unpredictable preferences that change over time; are dependent on a reference state of being; and are sensitive to information framing, anchoring and endowment effects, preference elicitation methods, risk-related attitudes, and 
cognitive heuristics $[9,12]$.

Application of these $\mathrm{Cll}$ theories and approaches to energy decision-making reveals several key lessons about individual energy behavior that apply to individual participants in community energy initiatives as well $[9,12,19]:$ 1) Utility \& Rational Choice Theories: some RE3 options are expensive with long payback periods, and with individual discount rates ranging from 5-300\%, loans may be more effective for residential DMs than rebates; 2) Information Deficit Model: energy issues are complex, and a general lack of DM understanding contributes to inaction; 3) Theory of Planned Behavior: RE3 interventions should include visual feedback on energy behavior and enhance individual perceptions of empowerment, leadership, and self-efficacy through access to skills, resources and training; 4) Theory of Planned Behavior: energy information should be simple, salient, personally relevant, easily comparable, and presented as trustworthy; 5) Theory of Planned Behavior: household characteristics (i.e., age, size, state of repair) are more accurate predictors of RE3 adoption than attitudes; 6) Altruism, Empathy \& Prosocial Theories: when basic needs have been met, altruistic motives may encourage RE3 adoption; 7) Appraisal \& Prospect Theories: energy behaviors depend on how information is presented, existing energy behaviors and habits, perceptions of risk associated with new technology, and perceived benefits/costs in different "mental accounts"; 8) Appraisal \& Prospect Theories: consumers may avoid decisions when there are too many choices (i.e., changing default settings on an appliance may be more effective at reducing energy use than trying to get people to break habits). Some of these lessons have been incorporated in new ways of implementing traditional approaches based on utility and rational choice theories. For example, BCA has advanced to include a wider variety of considerations in the form of social benefit-cost analysis; a wider variety of individual preferences through advanced preference elicitation methods; and more dynamic discount rates through uncertainty and sensitivity analysis.

\subsection{Context-dependent collective action literature}

Empirical evidence from behavioral economics, game theory and neuroscience indicate that more understanding of the effect of social context on individual behavior is needed in utility and rational choice 
models [20]. Theoretical framings from the fields of anthropology, sociology, and technology management complement this need for a more context-dependent collective action focus on behavior research.

Diffusion of Innovation Theory suggests that the adoption of innovations (by autonomous DMs) depends on social networks and occurs in stages: knowledge acquisition, persuasion, implementation, and confirmation, with varying behavior at different adopter stages (innovators, early adopters, early majority, late majority, laggards) [21]. Interventions should therefore target different adopter stages (assumes a heterogeneous population of consumers rather than homogeneous). In addition, individual energy consumers are more likely to adopt energy behaviors and technologies that have been adopted by people in their own social network with similar beliefs, attitudes, education, and status. Thus, providing opportunities for consumers to learn from early adopters' experiences with observable rather than hidden interventions (i.e., solar photovoltaic panels rather than insulation) may be effective at supporting widespread RE3 adoption [9].

In the context of Diffusion of Innovation Theory, "innovation" typically refers to the RE3 technology or behavior. A growing body of literature on sustainability transitions has begun to define community-led energy initiatives as "grassroots innovations", emphasizing the innovation of not only the RE3 technology but also the social innovation of creating a network of activists to lead bottom-up sustainable development solutions that respond to local situations and community interests [22]. In this view, community energy initiatives comprise a niche of sociotechnical innovation in which people practice new social infrastructure, institutions, value sets, and priorities in a value space that is distinct from the dominant regime (in this case centralized energy generation) [23], both because they are practicing new technology innovations and also because they are practicing new social decision-making and development innovations around those technologies. Strategic and Social Niche Management (SNM) theories (from evolutionary economics, technology management, constructivist science \& technology, and sociology) suggest this type of niche, if constructed appropriately, could act as a building block for broader societal changes toward sustainable development [13].

This suggestion is echoed in Social Practice Theory, which joins SNM in defining individual behavior as a result of a set of social practices that constitute and inform normal and routine ways of life 
(a CDC perspective) [15]. Changing energy behavior, therefore, requires targeting this larger set of social practices and culture (CDC perspective) in addition to providing information and incentives (CII perspective). In this way, Social Practice Theory supports the development of community energy as a means to change individual behavior because engaging individuals in a grassroots initiative disrupts the "normal way of life", causing individuals to practice the preferred behavior without expecting a prior individual shift in values. This social engagement may in turn lead to a shift in individual values after the behavior has been practiced.

An Integrated Model of Pro-Environmental Behavior [9] combines CII and CDC considerations to provide a more complete picture of the complexities around human decision-making. Although useful for visualizing the interrelationships between values, beliefs \& norms, and the importance of considering personal and contextual (individual \& shared) factors that affect behavior, the Integrated Model does not offer much detail on the effect of social interactions, culture, or practice on behavior, and it appears to consider behavior as a static condition. SNM from a Multi-Level Perspective (MLP) offers additional framing for the "contextual domain" factors (individual: socioeconomic status, technical skills, resources; \& shared: market actors, technologies, social interactions, norms, supply chain, economy, regulations) presented in the Integrated Model.

MLP, grounded in sociology and evolution, enriches SNM \& Social Practice theories by providing evidence that there are selective forces operating at different levels of cognition, which encourage selfish behaviors at the individual level and more altruistic behavior at the group level [14]. This perspective supports the Altruism, Empathy, and Prosocial Behavior theories that individual behavior can result from altruistic motivations, but adds another dynamic in the evolutionary observation that groups often perform better than the sum of their parts, revealing advantages to group participation that may not be achieved through individual action. MLP adds another dimension to SNM theory, demonstrating how social interactions advance through multiple levels of a socio-technical hierarchy (niche-innovations, sociotechnical regime, and exogenous landscape) and how these interactions change over time. Whereas the Integrated Model and a similar CII-based Model of Pro-Environmental Behavior [19] are useful in identifying barriers to pro-environmental behavior from a variety of disciplinary perspectives and theories, the SNM-MLP model extends these perspectives to show how bottom-up (niche-to-regime; regime-to- 
landscape) AND top-down (landscape-to-regime; regime-landscape) interactions create "windows of opportunity" that can advance social innovations. These windows open when landscape developments put pressure on the existing regime (top-down), and there is sufficient momentum from niche-innovations (bottom-up) to take advantage of this top-down pressure.

This view suggests that energy behavior change requires alignments of multiple processes at multiple levels of socio-technical interaction [13] and that socio-technical innovations at the niche level may encourage diffusion of innovation at the regime level. SNM theory identifies 3 key processes (managing expectations, building social networks, and learning) for successful niche growth and emergence and 3 ways in which niches can influence the regime (replication, growth in scale, and translation) [23]. These processes and pathways suggest the following indicators for measuring niche and regime diffusion, which have been previously examined in the context of UK Transition Towns (a grassroots community movement that includes community energy projects in addition to other sustainability initiatives - see Section 4.1) [23]:

\section{Project-Level Indicators of Niche Diffusion}

1. Expectations: widely shared, specific, realistic and achievable

2. Networking activities: include many different stakeholders, who share information and/or financial resources

3. Learning: include evidence of 'second-order learning' (questioning regime assumptions and constraints)

\section{Niche-Level Indicators of Regime Diffusion}

4. Replication: individual projects contribute to aggregative changes

5. Scaling-up: individual projects grow in scale and attract more participants from beginning to end of project timeline

6. Translation: niche ideas become integrated into mainstream settings 
Individual community energy projects may support diffusion by directly or indirectly influencing a variety of outcomes, including: niche level diffusion - additional community energy projects and/or individual RE3 adoption by community energy members, the formation of local RE3 companies and/or legally recognized organizations; regime level diffusion - RE3 adoption by non-member individuals, the formation of state, national, or international RE3 companies and/or legally recognized organizations, community energy policy implementation.

\section{What is community energy?}

The term "community energy" has many definitions and interpretations depending on the context in which it is used. The Guide to Developing a Community Renewable Energy Project in North America [24] defines community renewable energy" as "locally owned, locally sited renewable energy (electricity and/or heat)" with a community participation component that "reaches beyond a simple investment of shareholding relation". Hoffman, S. and High-Pippert, A. [25] acknowledge that the label "community energy" has applied to activities as diverse as individual residential photovoltaic (PV) solar adoption, small landowner groups involved in large wind turbine projects, and urban cooperatives supplying neighborhood heating and cooling services. They suggest that a "community energy initiative" can be defined by the degree of public participation, manner of governance, proportion of locally generated energy that is consumed locally, ownership structure, and the technology adopted. Walker, G. and Devine-Wright, P. [26] categorize many of these considerations in the two dimensions of process and outcome, where the former relates to the people who develop and run the project, and the latter relates to the people who receive the benefits of the project. They define an "ideal" community project as one in which a group of local people organize and operate the project and also receive the benefits of the project. An ideal community energy project, therefore, incorporates an open and participatory process with local and collective benefits.

Walker [27] classifies several existing models of community renewable energy ownership: cooperatives in which local people buy shares to finance a project; charities that provide facilities or 
services for the community; development trusts; and shares gifted by large energy developers to local community organizations. The last model is the most widely recognized by the U.S. government in the Department of Energy's guidebook Solar Powering Your Community: A Guide for Local Governments [28]. Heiskanen et al. [11] distinguish between geographically local communities, sector-based communities, interest communities and virtual communities in the context of examining behavior change in low-carbon communities.

These varied perspectives can be captured in an all-inclusive definition that focuses on a grassroots approach to community energy: a project or program initiated by a group of people united by a common local geographic location (town level or smaller) and/or set of common interests [24,28]; in which some or all of the benefits and costs of the initiative are applied to this same group of people [26]; and which incorporates a distributed energy generation technology (for electricity, heat, or transportation) based on renewable energy resources (solar, wind, water, biomass, geothermal) and/or energy conservation/efficiency methods/technologies. This definition excludes individual renewable energy distributed generation installations, which do not have a group component. It also excludes the prevailing market-based use of the term "community energy" in the US, which involves external firms initiating community renewable energy projects to earn revenue, while community-members buy into the projects as shareholders [29]. This market-based definition of community energy is not consistent with the theory of community energy as a socio-technical innovation (see Section 2.2); rather, it follows a more traditional capitalist, top-down model of renewable energy diffusion. Although we defined community energy with a grassroots focus, we also include market-based projects in our research, as the existence of both provides opportunities for comparative assessments of community energy dynamics, effectiveness, and limitations.

\section{What are the different ways in which community energy is being implemented?}

In the last 15 years, 76 articles have been published on the topic of community energy (Table 1). The vast majority of these articles (64) focus on renewable energy, with only three focusing exclusively on energy efficiency \& conservation, and nine including energy efficiency and conservation alongside renewable energy. Most community renewable energy studies cover renewable energy as a general topic 
or apply to all renewable energy technologies. Of those that focus on specific renewable technologies (33), most apply to solar (18) and wind (18). In addition, some focus on energy storage (5). Community energy articles cover a variety of geographic regions, with most centered on the UK (33) and other European nations (14).

\section{Table 1 - Summary of Community Energy Literature (see separated file)}

\subsection{Key Insights from non-US studies}

As Table 1 shows, most community energy studies have not targeted the US, and in fact most have focused on the UK and the rest of Europe. Ornetzeder and Rohracher [17] demonstrate how grassroots innovations in the form of community-led energy projects have been successful at producing widespread and lasting mainstream impacts. They show how three case study sustainable energy transitions - wind energy in Denmark, solar energy in Austria, and car sharing in Switzerland - began in response to a trigger event or set of events in the 1970s and 1980s; were sustained as a result of social or environmental (not financial) motivations; and continue to have lasting impacts on energy policy, technology and development. For example, in the wind energy case, activists united to promote energy alternatives to nuclear power and over the course of 11 years, conducted experiments with small-scale wind turbines. These community-based experiments grew into a larger social movement that resulted in Denmark becoming one of the leading nations in wind energy in the world. The technology developed in these initial experiments continues to influence the design principles of modern wind turbines all over the world. Parag et al. [71] recognize that communities are "important agents for bottom-up policy change as they have the potential to create the political space and support that local government needs in order to introduce energy related policies and programs". They propose that this political momentum could translate to change in national sustainable energy action through links between communities and campaigning organizations.

Seyfang and Haxeltine [23] demonstrate how community-led climate change and energy 
initiatives can be regarded as a grassroots innovation by examining the UK Transition Towns (TT) movement through a SNM framework. The TT movement began in 2005, and involves a network of around 400 independent community-led projects in the UK and internationally that are designed to "mobilize community action and foster public empowerment and engagement around climate change". Seyfang and Haxeltine examine the effectiveness of the TT movement at enabling the diffusion of innovative ideas and practices through three possible diffusion pathways (replication, scaling up, and translation). They find that while the movement has been very successful at replicating its model of community-led initiatives, scaling up is a problem as initial local attention and interest surrounding new TTs usually wanes to a small core group of activists who struggle to recruit more members. They conclude that it is too early to tell how well TT ideas have translated to mainstream society; some of the key messages of the TT movement are increasingly seen in mainstream discourse - though the TT movement probably cannot claim sole credit for these cultural transitions.

Seyfang and Haxeltine [23] also examine how successful TTs have been at niche development and growth, as defined by SNM theory to depend on the management of expectations and visions, networks, and learning processes. In this regard, the authors find that many TTs struggle to adhere to concrete expectations that produce action, causing frustration and desertion by group members who feel they are suffering "death by meeting". Networking has been instrumental to the TT movement's rapid growth but has largely remained internal. TT communities have begun the process of building a bridge to local government, which Seyfang and Haxeltine recognize as one measure of the progress of a niche community toward fostering a wider societal transition. However, TTs have been less active in building links to other regime actors such as non-governmental organizations, businesses, charities, social enterprises, political parties, and national government. In terms of learning, TTs incorporate second-order learning (a high level of understanding and questioning) by the nature of the movement being involved in societal transformation. Despite this, the authors question the effectiveness of some of the learning methods, including recommended awareness-building activities and films with high 'doom ratings' and low 'solutions ratings' that even committed activists find difficult to watch. Overall, Seyfang and Haxeltine conclude that the TT movement is an example of successful niche formation in several respects, but that 
there are significant weaknesses in the niche processes, which limit the potential for this grassroots innovation to achieve more widespread diffusion. They provide suggestions for strengthening these niche processes: foster realistic and achievable expectations; network outside the movement with resourceful stakeholders; and adopt social and experiential learning strategies.

More recently, van der Schoor, T. and Scholtens, B. [36] conducted a case study of 13 local community energy initiatives in the Netherlands that include biomass, solar PV, energy efficiency, water, and solar thermal in villages and cities of varying size. They conducted qualitative interviews, observations during meetings and events, and small-scale surveys to understand the ways in which these initiatives were situated in two dimensions - attachments to outside networks and the commitment of members. Their conclusion is that while community energy provides a useful way for citizens to engage in grassroots action, there is a need for more development or organizational structures and goals in order to achieve lasting results.

Dóci G. and Vasileiadou E. [54] examine individual motivations for investing in renewables at the community level through four case study communities in Germany and the Netherlands with energy projects as diverse as a combined biogas power plant to solar houseboats. They apply 3 goal frames to these communities: hedonic (increase pleasure; short-term); gain (increase/protect resources; mid-long term); and normative (comply with social norms, ethics, and morals; short-long term). Results indicate that gain and normative considerations drive participation in community energy initiatives, including decreasing energy costs and reducing climate change threats, respectively. However, hedonic motivations are also present to a lesser extent, including having fun and integrating in a community. In addition, they confirm trust is an important condition for the success of local energy projects.

\subsection{Community Energy in the US}

Eight studies have examined community energy case studies in the United States. VanHoesen and Letendre [100] use a Geographic Information System (GIS) to assess the energy resource potential in a rural Vermont town for biomass, wind, and solar technologies. They also discuss the non-profit 
Vermont Clean Action Network (VECAN), which unites and supports towns committed to community energy by providing information, technical assistance, and facilitating networking among communities and resource providers [101]. VECAN has recently begun providing guidance and support on community solar to member communities. Vergragt and Brown [31] discuss a community energy experiment in Worcester, MA initiated by faculty members at Clark University in response to challenges associated with retrofitting homes to be more energy efficient. Vergragt and Brown argue that homeowners should be viewed not just as individually acting rational economic actors - as they have been in the leading municipal residential energy efficiency programs in Cambridge, MA and Berkeley, CA - but also as "community members acting in a social and cultural context". They hypothesize that bounded socio-technical experiments (collective endeavors by diverse stakeholders who agree to try out new strategies, learn by doing, and commit to a long term vision of advancing society's sustainability agenda) will help overcome these challenges by engendering higher order learning.

Hoffman and High-Pippert [25] demonstrate through two Minnesota case studies how the actions of a few committed citizens can "transform the disparate acts of minimally engaged citizens into an effective community-based program" with renewable energy, energy efficiency, and conservation goals. In the two case studies, successful recruitment depended on personalized strategies or "acts of neighborliness", such as being recruited by someone they knew personally or by an organization with which they were already involved. A letter to the editor of a local newspaper that presented a call to civic duty was also successful at engaging citizens. Hoffman and High-Pippert note that other initiatives have been successful when they link their initiatives to shared community assets, such as schools, which become a source of community pride and an educational opportunity. The two Minnesota case studies support the findings of Funk [102] and Verba et.al [103] that people are motivated to participate in community affairs at least in part by benefits that relate to social and civic gratification (enjoyment of working with others and fulfilling a sense of civic duty, respectfully). Community renewable energy projects in this way may offer an additional benefit of countering an era of declining civic engagement [104]. Both case studies retained members by providing a rich environment for social and civic engagement through framing the initiatives as a way to build strong communities, fostering networking, 
and working together toward a common goal with collective benefits (i.e., increased local employment, reduced emissions).

Yin [99] uses Actor-Network Theory (ANT) to examine seven community wind cases in Oregon through 12 ethnographic interviews with project developers, project owners, and government officials in order to identify common opportunities and barriers. Three of the projects had been completed or were close to being completed at the time of the study; one was likely to succeed; one was too early to tell; and two had either already failed or were likely to fail. Yin identifies 13 common factors between the wind projects: geographic features, land ownership, local attitudes, wheeling utilities, power buyer, county, state, federal, and other incentives, financing sources, manufacturers, developers, and conservation groups. Important barriers include the collapse of the financial sector, difficulty in securing construction financing, and public opposition due to scenic or cultural property and endangered species. Opportunities include the federal investment tax credit, construction loans, being surrounded by other large wind projects, having examples of similar projects, government support in securing transmission lines, guidance from the Bureau of Land Management, and investment by private individuals and companies.

Noll et al. [95] identify and characterize the operations of 228 US Solar Community Organizations (SCOs) - formal or informal organizations and citizen groups that help reduce barriers to the adoption of solar energy by providing information and/or campaigning for solar adoption. Noll et al. study the solar peer effect: "measured influence of an individual's neighbors, colleagues, or friends on his or her attitude, behavior or other outcomes related to his or her decision to adopt PV". Their national survey reveals most states with a high concentration of SCOs - Massachusetts (31), Oregon (23), District of Columbia (21), and California (18) - also have some of the highest electricity prices and most favorable solar policies in the US. In addition to the national survey, the authors examine four case studies in Arizona, Oregon, and Texas. Their primary conclusions are that SCOs tend to grow out of shock events that cause heightened public concern about energy sources and environmental impacts; and existing trust networks are crucial to the development of SCOs.

Booth [96] and Feldman et al. [105] discuss the impact of federal securities regulation on shared 
solar in the US. Federal securities regulations limit the amount of crowdfunding community solar projects can access and determine whether shared solar projects constitute a "security", which is regulated by the Securities Exchange Commission in a way that can greatly impact the way the project operates. Without existing legal precedent, US shared solar projects must be structured very carefully, often adding to the expense of the projects. Several states have proposed rules to help provide clarity for shared solar in this legal space, but there is still much uncertainty. Feldman et al. [105] also characterize the state of shared solar, which they interpret as solar farms or gardens but not buying groups or municipal solar. They project that by 2020 , shared solar could represent more than half of the total US distributed solar PV market, even though just two years ago, shared solar made up less than $1 \%$ of the market. This analysis underscores the pace at which community energy is growing in the US.

In addition to these published US-based studies, the federal and state governments have published several guidebooks, brochures, and factsheets specific to residential and community-based solar energy in the last seven years [106]. The Department of Energy (DOE) guide Solar Powering Your Community: A Guide for Local Governments [28] includes best practices from the DOE 25 Solar America Cities program, which was "designed to complement top-down federal policy approaches with federallocal partnerships that are helping to build a robust U.S. solar market". The DOE's Solarize Guidebook: A Community Guide to Collective Purchasing of Residential PV Systems [107] describes the first "Solarize" campaign, which "began as a grassroots effort to help residents of Portland, OR, overcome financial and logistical barriers to installing solar power", along with subsequent projects that built off of the Solarize Portland project. It also serves as a roadmap for others who want to replicate the Solarize campaign in their community. The successful case study communities showcased in the DOE Sunshot Initiative suggest that community-based renewable energy projects in the U.S. are on the rise.

\subsection{US Community Energy Database}


Currently, there is no single source of data on community energy projects or programs in the US, and there are a wide variety of initiatives included under the umbrella term community energy. We compiled data from existing publicly available sources into a new US Community Energy Database. We are in the process of integrating this database with a global database based out of the UK [108], in order to make it publicly available.

\subsubsection{Methods}

The US Community Energy Database was compiled through an internet search of "community energy" projects in the US. The following data were collected on each project: project name, location, contact information, energy technology, and descriptions of financial and organizational structures. These descriptions were coded for similar themes in order to create a new community energy classification system that includes the most common combinations of organizational and financial structures observed in the projects.

\subsubsection{Data sources}

The Transition Network [109] provides a searchable database that lists Transition Towns around the world by country, major theme (i.e., education, health, energy, housing, etc), community type (i.e., urban, rural, island, etc.), and status (i.e., "muller" - thinking about forming an initiative, or "official"). This database currently lists 36 official and 104 muller projects related to energy, two of which have implemented tangible energy efficiency, or conservation programs (no renewable energy installations). For example, Transition Town Charlotte, of Charlotte Vermont, facilitated over 70 home energy visits in which trained volunteers assessed home energy use and made recommendations for conservation and efficiency. Much more common among TTs are projects such as "re-skilling" workshops, in which TT members teach self-sufficiency skills including preserving, composting and gardening, and time banks, in which members volunteer their own time to help others and receive a credit which can be exchanged for 
an equal amount of aid in return. For instance, a person could exchange one hour of lawn mowing for one hour of child-care. Many TTs also organize awareness-raising activities; popular projects include screening documentaries and hosting book discussions around the issues of climate change and peak oil.

The US Environmental Protection Agency's (EPA's) Local Climate and Energy Program [110] provides a list of 50 Climate Showcase Communities - local governments and tribal nations that have implemented cost-effective and replicable community-based greenhouse gas reduction pilot projects. Of these 50 projects, 12 include renewable energy and 41 include energy efficiency or conservation. Other projects may relate to energy in a more indirect way and include diverting commercial food waste from landfills, upgrading public transit vehicles to include features like WiFi and make public transportation a more attractive option, and installing signs on existing bicycle routes displaying distance and average travel times to destinations such as parks, libraries, school and downtown areas. The EPA's State Climate and Energy Program [111] includes profiles of 32 state government initiatives to address climate change and encourage clean energy in government facilities and operations. While not directly related to local community energy initiatives, many of these states provide additional financial incentives and other policies that may help encourage and support community energy development. For example, the Pennsylvania Department of Environmental Protection provides educational materials, resources and assistance to local governments in developing and implementing energy management plans.

Certain state-based entities maintain particular types of community energy data. The Vermont Energy and Climate Action Network is a network of organizations that facilitates energy efficiency, conservation, and renewable energy projects in local municipalities across the state [112]. Coordinated by the Vermont National Resource Council, VECAN serves as a source of information and technical assistance for these projects, while also promoting networking and collaboration among local government energy committees. The VECAN Coordinator provided data on renewable energy and energy conservation projects throughout the state of Vermont, many of them community-based [113]. Additionally, the Minnesota Department of Commerce, Division of Energy Resources [114], compiled a spreadsheet of 27 community-based renewable energy projects (mostly wind), developed since the passage of legislation in 2005 incentivizing these projects. 
Data on community solar projects are more widely available than any other single energy option. The Solar Foundation [115] has amassed the most comprehensive database to date of K-12 schools with solar energy systems, most of them photovoltaic. These 3,752 schools have a combined power generation capacity of 490 MW. Furthermore, the DOE's Solarize Guidebook outlines several case studies for the Solarize model of community renewable energy implementation. Solarize campaigns take advantage of collective purchasing to enable community members to install residential photovoltaic systems more cheaply than they could as individuals. Such campaigns have become a popular method of renewable energy deployment; indeed the Massachusetts Clean Energy Center [116] provides data on the 40 Solarize projects that have been successfully implemented in MA alone. In addition, the National Renewable Energy Laboratory (NREL's) Open PV Project [117] compiled a comprehensive database of solar PV installation data for the US, voluntarily reported by a variety of sources including utilities, installers, and the general public. Unfortunately, there is no way to distinguish which of these projects might be community based, rather than individual or commercial.

Farrell, J. [118] provides the most in-depth analysis currently available of operational US community solar projects using different financial models, providing grades for nine projects based on their ability to overcome financial and institutional barriers, expand general participation in solar projects, make solar more affordable, install solar on existing structures rather than open spaces, and provide a replicable model for others to follow. Only two out of the nine projects earn an A-grade: the Mid-Valley Solar Array (A) owned by Holy Cross Energy in El Jebel, Colorado (known as the Clean Energy Collective in the report) and University Park Solar in Maryland (A-). The Mid-Valley Solar Array is the first community-owned "solar garden" implemented by the Clean Energy Collective (CEC), a company that builds purchasing groups in coordination with local utilities [119]. In 2010, CEC worked in conjunction with the collectively owned utility Holy Cross Energy to install a $77.7 \mathrm{~kW}$ array, from which customers could purchase 50-year ownership shares. In the last four years, CEC has expanded this concept, which earned an A for being a replicable model in 2010, and had a projected shareholder savings of approximately $\$ 3,000$ compared to individual ownership [118], to 35 current projects in various stages of development in Colorado, Kansas, Massachusetts, Minnesota, New Mexico, Vermont, and Wisconsin. 
University Park Solar is a for-profit private membership limited liability company (LLC) formed in 2010 , to take advantage of federal tax incentives associated with a $23 \mathrm{~kW}$ solar installation on a local church [118]. LLCs are a "hybrid type of legal structure that provides the limited liability features of a corporation and the tax efficiencies and operational flexibility of a partnership" [120]. Groups that might otherwise form a non-profit organization in order to promote renewable energy installation often choose to become a LLC instead in order to take advantage of financial incentives (i.e., the federal renewable energy tax credit [121]) and to avoid the lengthy and complex process of establishing non-profit status. Although there are several advantages to forming a LLC instead of a non-profit or a corporation, University Park experienced obstacles related to Securities and Exchange Commission rules for LLCs that restricted them to in-state investors and did not allow them to advertise other than by word-of-mouth. For these reasons, University Park received a grade of $C$ as a replicable model [118]. However, proposed federal and recently implemented state crowd-funding rules may make this model more replicable for future community-based renewable energy installations [122].

Other projects discussed in Farrell, J. [118] include two installations on government property financed through grants and/or donations (58 kW Ellensburg, Washington and $5 \mathrm{~kW}$ Solar for Sakai school project in Washington); one other LLC designed as a teaching project (Appalachian Institute for Renewable Energy (AIRE) Greenhouse Solar Project in North Carolina); and different types of "solar gardens": three power purchase agreement (PPA) leasing arrangements through a private, cooperative, or municipal utility to the utility member-customers (10kW United Power Sol Partners in Colorado, $10 \mathrm{~kW}$ Florida Keys Electric Cooperative (FKEC) Simple Solar Program, and 64 kW City of Ashland, Oregon Solar Pioneer) and one shared-ownership arrangement between two utilities and their customers (100 kW City of St. George Sunsmart). Farrell, J. estimates the simple payback period for an individual investor in each of the community solar projects to be between 5 and 34 years depending on the project (based on $2.1 \mathrm{~kW}$ system size per individual investor and $2 \%$ inflation), with University Park having the shortest payback period and City of Ashland Solar Pioneer having the longest. Farrell, J. estimates these payback periods to be 4 to 26 years shorter than the simple payback period for a similar size $(2.1 \mathrm{~kW})$ individual installation in the same state for the Mid-Valley Solar Array in Colorado, University Park in Maryland, 
AIRE Greenhouse in North Carolina, and Ellensburg, Washington projects. However, the AIRE and Ellensburg projects used one-time funds that are not likely to be replicable for future projects. The remaining projects had simple payback periods 1-17 years longer than the comparable individual (noncommunity-based) investment.

Though less prolific than the data available on community solar, information regarding community wind projects is also accessible. The American Wind Energy Association [123] lists 89 community wind projects nationwide, along with each project's generating capacity. Data on wind projects in the state of Illinois, many of them community-based, are also available through Illinois State University's Center for Renewable Energy [124].

\subsubsection{Results: Community renewable energy classification system}

Through the process of compiling these community energy data and preparing the dataset for use in future research, we recognized the need for a community energy classification system of the various community energy financial models currently being discussed under the heading "community energy" in the US. As discussed in Section 3, Walker [27] presents a classification system for community renewable energy in the UK that includes cooperatives, charities, development trusts; and share donations. NREL presents a classification system for community solar projects that includes three primary models [125]: 1) utility-sponsored (a utility owns or operates a project that is open to voluntary ratepayer participation); 2) special purpose entity (SPE - individual investors join a business enterprise to develop a community solar project); and 3) non-profit "buy a brick" (donors contribute to a community installation owned by a charitable non-profit corporation). NREL identifies several types of SPEs: general partnerships, limited partnerships, limited liability companies, cooperatives, "S" corporations limited liability, "C" corporation limited liability, and non-profit entities. Table 2 extends these existing classification systems based on research discussed in Section 4.3.2 and describes 8 community renewable energy financial models, identifying the respective roles of internal and external stakeholders in each model. Energy efficiency and conservation programs are not included in this classification system because our preliminary research 
has discovered these programs are much more diverse and more difficult to categorize than community renewable energy projects. More time and research is needed to develop a comprehensive classification system for community energy efficiency and conservation programs.

\section{Table 2 - Community Renewable Energy Classification System (see separate file)}

Specific stakeholders involved in purchasing RE systems typically include local governments, municipal, cooperative, or private utilities, individual homeowners, non-profit organizations (often schools and churches), corporations, and small LLCs. The stakeholders who initially purchase the installation (A) are not necessarily the same stakeholders who physically host the installation on their property (B), own the installation over the long term (C), pay the maintenance costs on the installation (D), or receive the annual energy savings or annual financial incentives (F). The classification system illustrates the dynamics between community members (1) and entities external to the community (2) in different model types and defines the community members. Following from the discussion in Section 3, the definition of community for each financial model changes depending on the model type, and the level of involvement in the project $(\mathrm{H})$ and interaction between community members $(\mathrm{I})$ can be very different depending on the model type. In addition, the entities external to the community involved in any one model type may take very different forms. For example, in a PPA (Models 5 and 6 ) the external entity could be a municipal, cooperative, or private utility selling renewable electricity to the "community" of utility customers (i.e., City of Ashland Solar Pioneer, United Power's Sol Partners, FKEC [118]). In the case of a private or municipal utility, community member involvement may be limited to just signing up for the program with no further action or interaction with other community members required or available (resulting in a label of $L$ for low in both categories $\mathrm{H}$ and I). Alternatively, the external entity could be a LLC formed specifically for the purpose of installing a solar array on a church or other building belonging to a tax-exempt organization that cannot take advantage of the federal tax credit for renewable energy installations (i.e., University Park and AIRE [118]). In the latter case, the "community" would be the members of the church or other 
organization that hosts the renewable energy installation. These members may also (but not necessarily) be the member-owners of the LLC, in which case they would receive high $(\mathrm{H})$ levels for project involvement $(\mathrm{H})$ and community interaction $(\mathrm{H})$. Both examples use a PPA as the financial mechanism but the resulting projects look very different and the level of individual involvement and community interaction are very different.

Table 2 compares two types of buying groups formed in order to take advantage of group purchasing power for individual renewable energy installations (Model 1) or renewable energy electricity (Model 2). Model 1 groups accomplish this by contracting with a single supplier or by certifying a select group of trusted suppliers from which individuals can obtain quotes, introducing an element of competition for the lowest bid. The Solarize campaign [107], and renewable energy cooperatives such as the Mount Pleasant Solar Cooperative in Washington, D.C. [118] and those united by DC Solar United Neighborhoods [126] are examples of this model. Farrell, J. calculates the net installed cost of a $2.1 \mathrm{~kW}$ solar array and simple payback period for a Mount Pleasant Solar Cooperative member to be approximately $\$ 1,800$ and 2 years, respectively, compared to similar calculations for a non-member at $\$ 5,500$ and 5 years, respectively. Generally, this model requires a high level of individual involvement because the individual usually installs renewable energy on his/her own property. Depending on program specifics, the level of community interaction could be low (i.e., individuals receive information and complete transactions by phone, email, or mail and maybe attend one information session) to high (i.e., individuals for an active community group that celebrates installation milestones together and meets regularly to discuss, plan, and act on related sustainability ideas and initiatives).

The motivations for forming Model 2 groups are not necessarily linked to achieving economies of scale and accessing discounts associated with group purchasing. Community Choice Aggregation (CCAs) [127] involves a municipality or county forming a public agency to buy renewable energy generation for their residents, with the option for residents to opt-in or opt-out of the program. The program is created for the community of residents that opt-in to the program, and they are the group of people united by a common theme. Therefore, they are the specific community targeted in that model. The public agency acts as a liaison between the renewable energy generator(s) and the residents, but 
does not otherwise actively engage in costs and benefits, hosting or owning generation. Most often, a private company external to the community owns the generation, serving as the initial investor (A), project host (B), long-term owner (C); pays the annual operation and maintenance costs of the renewable energy system (D); receives all upfront financial incentives such as the federal tax credit, state rebates, etc $(F)$; and receives any tradable renewable energy credits that are available $(G)$. Although CCAs try to provide competitive pricing, some may require community members to pay an initial fee to join in order to cover the cost of renewable energy investment. Six states allow CCAs (Massachusetts, Ohio, California, Colorado, Rhode Island, and New Jersey). CCAs in Ohio and Massachusetts purchase renewable energy from independent power producers and sell it back to the community, while "utility model" CCAs (i.e., in California) can directly invest in renewable energy projects, and others purchase renewable energy credits (RECs) rather than actual electricity [127]. Green Pricing programs [118] are another example of Model 2, but in contrast to CCAs these programs are more widely available (in over 40 states [128]), run exclusively by utilities, and nearly always require customers to pay a premium on their electric bills to cover the incremental cost of additional renewable energy. Farrell, J. gives these programs an F for affordability, arguing that current market conditions provide much more affordable ways for individuals to support renewable energy than these "outdated" programs [118]. Model 2 generally requires low to moderate individual involvement depending on what the individual actually has to do to opt-in or out of the renewable energy electricity purchase, and it generally does not involve any community interaction.

Models 3 and 4 are similar to each other in that they include communities directly connected by geography, actually living in the same neighborhood, but are different in intention and level of community involvement. In Model 3, an external investor and/or building contractor constructs a Green Planned Housing Development with the intention of selling the homes to buyers with a preference for sustainable living. The investor/contractor may or may not have morals, ethics or beliefs aligned with sustainable living; regardless, he/she will typically be trying to make a profit on the investment and not necessarily be primarily motivated to unite a community of like-minded individuals toward sustainable change. The level of individual involvement ranges from moderate to high in this model because on one hand an individual may simply decide whether or not to purchase a home while considering the costs and benefits of existing 
renewable energy on the property (moderate); on the other hand, the individual may have the opportunity and flexibility as part of his/her purchase to select specific renewable energy options for the newly constructed house (high). Community involvement can range from low to high because individuals could choose to have little to no contact with their neighbors (low) or they could become united by a sustainability mission, goals, activities, etc (high). The Clarum Homes in Watsonville, California [129] appear to be an example of a development that may not encourage much community interaction, while the Geos Neighborhood in Colorado [130] may offer more opportunities for community interaction.

Model 4 requires a higher level of individual involvement and community interaction by its very nature: a group of people with similar morals, ethics and/or beliefs choose to live together and abide by a set of guiding principles related to sustainability. The Fellowship for Intentional Community (FIC) [131] provides a searchable database of communes (organized around sharing almost everything), ecovillages (organized around ecology and sustainability), cohousing (individual homes within group owned property), shared housing (multiple individuals sharing a dwelling), and other intentional communities in the US and other countries. FIC lists 130 communities in various stages of development committed to incorporating renewable energy. For example, Elemental Eden is an ecovillage in Mora, New Mexico formed by builders and solar installers, committed to achieving up to $90 \%$ renewable energy generation (solar and wood). Residents in this community share meals 1-3 times per month, incorporate other sustainable living routines (i.e., composting human waste, organic local food sourcing, gray water recycling, collecting rain water in cisterns), and have regular community gatherings.

The simplest community financial model (Model 5) involves the use of one-time funds to pay for all or part of the installation cost. For example, a church, school or other non-profit organization might run a fundraising campaign and pay for the installation with donations. Alternatively, the organization might qualify for grant funding through a government agency or private entity. A municipality that installs renewable energy on government property will typically use one-time funds in the form of tax revenues. A cooperative business or utility using internal profits or savings to fund a renewable energy installation is another example of this model. Often, this model will be combined with other models. For example, a 
cooperative utility may use internal funds to pay for part of the upfront cost of a solar array and then sell electricity through a PPA (Models 6 \& 7) to recover some or all of the upfront cost over time.

The term "Solar Garden" has recently become a popular catch phrase for community solar installations [132]. However, as Table 2 shows, the term may have different meanings depending on the specific nature of the project. Models 6,7 , and 8 may all be included under the umbrella heading solar garden, and each of these models could have different specific arrangements regarding who plays the role of external entity and community and what level of individual involvement and community interaction is required/encouraged. Therefore, it is important for potential stakeholders to pay attention to the specific details of the financial model rather than assuming all projects under the same headline category are the same.

The Community Renewable Energy Classification does not offer a clear distinction between grassroots and market-based community energy financial models. In fact, Model 3 is the only one that clearly falls under the market-based definition, and Model 4 is the only one that clearly falls under the grassroots definition, as discussed in Section 3. Model 1 is likely to be more market-based than grassroots when applied in the Solarize context, but the RE Cooperative context has a strong grassroots element. Model 2 applied in the Community Choice Aggregation context could have a grassroots element, while the Green Pricing application is clearly market-based. Model 5, applied as a private utility using internal profits to pay for a RE installation combined with a subsequent PPA, would be marketbased, while an installation on a church, school or other community organization paid for by donations would clearly be grassroots. Models 6-8 are typically market-based. However, a project like University Park Solar in which an LLC was specifically formed for the purpose of installing solar on a community building, is clearly grassroots. Future research will compare the relative prevalence, costs, benefits, barriers, and opportunities to each of these financial models of community renewable energy in the US and the specific grassroots versus market-based applications of each.

\section{Conclusion}


In this article, we presented a literature review of: the theoretical foundations for focusing on community energy as a path to energy behavior change (Section 2); various definitions of community energy - distinguishing between grassroots and market-based definitions (Section 3); and global community energy studies (Sections 4.1-4.2). We also presented a new US Community Energy Database that will soon become publicly available and introduced a new classification system for community renewable energy based on this database (Section 4.3). Context independent individualistic theories and programs focus on changing the behavior of the individual, often in isolation from the individual's social network or community. While these theories and programs have been successful to a certain extent in improving methods to change individual behavior, context-dependent collective action theories and programs suggest incorporating a social or community component may be more effective in encouraging more long-lasting renewable energy, energy efficiency and conservation behaviors. The community energy label can describe a wide variety of projects. In a grassroots model, local people are engaged in the organization and operation of a project and share in its benefits. However, market-based models, in which a firm develops a project and community members buy-in, can also be effective and provide economic and social benefits.

The community energy literature review revealed many benefits of community energy as well as several lessons for future research and development. Benefits: producing widespread and lasting mainstream impacts (e.g., influencing design principles of modern wind turbines all over the world) [17]; supporting sustainable energy policies and programs, from local to national levels [71]; fostering secondorder learning [23]; providing a useful way for citizens to engage in grassroots action [36]; decreasing energy costs, reducing climate change threats, having fun, integrating in a community [54]; increasing social and civic gratification (enjoyment of working with others and fulfilling a sense of civic duty, respectfully) [25][102] [103]; building strong communities, fostering networking, working together toward common goals with collective benefits (i.e., increased local employment, reduced emissions) [25]; reducing barriers to adoption [95]; reducing payback periods [118].

Lessons for future research and development: Efforts to define, categorize, intervene, and assess the community energy "sector" are necessary but must incorporate multi-criteria approaches (i.e., 
considering more criteria than emissions reductions or energy production) that recognize the difficulties of integrating multiple sets of objectives (often unrelated to energy and climate change), a variety of member types and organizational structures, multi-faceted approaches to action, and a wide range of strategies and technologies to achieve a diverse set of goals [72]. Civic engagement is a strong motivator for community energy member recruitment \& retention [25] and fundamental to the character of community energy initiatives; this is a major strength in that it fosters stronger group relations and momentum, but it is also associated with project-related weaknesses from lack of time, volunteers, money, and material resources that are difficult to overcome internally [72]. In addition to these intrinsic challenges, there are external "diffusion" challenges to transferring learning from individual community energy projects to the niche or regime level: lessons are often context-dependent and location-dependent; community energy members are often not interested in transferring knowledge outside of the local arena - valuing the local, grassroots nature of the project in and of itself; competition from more powerful mainstream groups may reduce social benefits associated with community energy; policy-maker tend to be risk averse when dealing with small-scale, often radical and informal innovating organizations [70]. Although the community energy movement is growing rapidly in the UK, these challenges, among others, have limited the level of diffusion of community energy projects from the niche to regime levels [50][23]. Niche intermediaries can help mitigate these intrinsic \& diffusion challenges and accelerate the transition of community energy as a socio-technical innovation by: 1) aggregating knowledge across a variety of local projects; 2) developing institutional infrastructure to collect, exchange, and circulate this aggregated global knowledge; 3 ) providing advice, guidelines and templates to help in the development of new projects, while recognizing each project will have a unique set of characteristics and challenges and 4) brokering and managing partnerships between projects and external actors (i.e., energy companies, regulators, etc.) [70]. Successful approaches to building confidence and capabilities (critical in early stages to maintain momentum) often require intermediaries to provide a high level of resource-intensive support, including face-to-face mentoring and training [70][71].

The new US Community Energy Database we present in this article includes projects identified through internet search, which are grouped into eight new financial/organizational classifications: buying 
group 1 - installation; buying group 2 - electricity; green planned housing development; intentional sustainable communities; one-time funds; power purchase agreement; power purchase agreement with lease option; and shared ownership. With the exception of the green planned housing development and intentional sustainable communities, which are clearly market-based and grassroots, respectively, each model has the potential to be applied in a more market-based or grassroots fashion depending on the specific arrangements between community members and external entities.

Future research will continue to add US community energy projects to our growing database, which will be linked to an existing UK community energy database; compare the relative prevalence, costs, benefits, barriers, and opportunities (including opportunities for advancing more widespread sustainable energy diffusion) to each of the financial models presented in the Community Renewable Energy Classification; compare specific grassroots versus market-based applications of each model; and analyze the potential of existing and proposed policies for supporting replicable models of community energy that maximize benefits.

\section{ACKNOWLEDGEMENTS}

This work is/was supported by the USDA National Institute of Food and Agriculture, Hatch project 0230040.

\section{REFERENCES}

[1] Energy Policies of IEA Countries: the United States. International Energy Agency; 2007. 
[2] US EPA CCD. Global Greenhouse Gas Emissions n.d. http://www.epa.gov/climatechange/science/indicators/ghg/global-ghg-emissions.html (accessed June 26, 2014).

[3] Committee on Health, Environmental, and Other External Costs and Benefits of Energy Production and Consumption; National Research Council. Hidden Costs of Energy:Unpriced Consequences of Energy Production and Use. Washington, D.C.: The National Academies Press; 2010.

[4] U.S. Energy Information Adminstration. Annual Energy Review n.d. http://www.eia.gov/totalenergy/data/annual/ (accessed June 15, 2014).

[5] Scene Consulting. Energy Archipelago 2015. http://beta.energyarchipelago.com/\#/map.

[6] Bob Everett, Godfrey Boyle, Stephen Peake, Janet Ramage. Energy Systems and Sustainability: Power for a Sustainable Future. New York: Oxford University Press; 2012.

[7] National Academies. What you need to know about energy n.d. http://needtoknow.nas.edu/energy/ (accessed May 6, 2014).

[8] Sustainable Energy for All n.d. http://www.se4all.org/about-us/ (accessed July 18, 2014).

[9] Wilson C, Dowlatabadi H. Models of Decision Making and Residential Energy Use. Annu Rev Environ Resour 2007;32:169-203. doi:10.1146/annurev.energy.32.053006.141137.

[10] Scott E. Page. Path Dependence. Q J Polit Sci 2006;1:87-115. doi:10.1561/100.00000006.

[11] Heiskanen E, Johnson M, Robinson S, Vadovics E, Saastamoinen M. Low-carbon communities as a context for individual behavioural change. Energy Policy 2010;38:7586-95. doi:10.1016/j.enpol.2009.07.002.

[12] Camerer CF, Loewenstein G, Rabin M. Advances in Behavioral Economics. Princeton University Press; 2011.

[13] Schot J, Geels FW. Strategic niche management and sustainable innovation journeys: theory, findings, research agenda, and policy. Technol Anal Amp Strateg Manag 2008;20:537-54. doi:10.1080/09537320802292651.

[14] Wilson DS, Vugt MV, O'Gorman R. Multilevel Selection Theory and Major Evolutionary Transitions Implications for Psychological Science. Curr Dir Psychol Sci 2008;17:6-9. doi:10.1111/j.14678721.2008.00538.x.

[15] Tom Hargreaves. Practice-ing behaviour change: Applying social practice theory to proenvironmental behaviour change. J Consum Cult 2011;11:79-99. doi:10.1177/1469540510390500.

[16] Til JV, Hegyesi G, Eschweiler J. Grassroots Social Movements and the Shaping of History. In: Cnaan RA, Milofsky C, editors. Handb. Community Mov. Local Organ., Springer US; 2007, p. 362-77. 
[17] Ornetzeder M, Rohracher H. Of solar collectors, wind power, and car sharing: Comparing and understanding successful cases of grassroots innovations. Glob Environ Change 2013;23:856-67. doi:10.1016/j.gloenvcha.2012.12.007.

[18] Circular A-4 | The White House n.d. http://www.whitehouse.gov/omb/circulars_a004_a-4 (accessed July 18, 2014).

[19] Kollmuss A, Agyeman J. Mind the Gap: Why do people act environmentally and what are the barriers to pro-environmental behavior? Environ Educ Res 2002;8:239-60. doi:10.1080/13504620220145401.

[20] Gowdy JM. Toward an experimental foundation for benefit-cost analysis. Ecol Econ 2007;63:64955. doi:10.1016/j.ecolecon.2007.02.010.

[21] Rogers, Everett. Diffusion of Innovations. New York: Free Press; 2005.

[22] Seyfang G, Smith A. Grassroots innovations for sustainable development: Towards a new research and policy agenda. Environ Polit 2007;16:584-603. doi:10.1080/09644010701419121.

[23] Gill Seyfang, Alex Haxeltine. Growing grassroots innovations: exploring the role of communitybased initiatives in governing sustainable energy transitions. Environ Plan C Gov Policy 2012;30:381-400. doi:10.1068/c10222.

[24] Guide to developing a community renewable energy project in North America. Quebec, Canada: Secretariat of the Commission for Environmental Cooperation; 2010.

[25] Hoffman SM, High-Pippert A. From private lives to collective action: Recruitment and participation incentives for a community energy program. Energy Policy 2010;38:7567-74. doi:10.1016/j.enpol.2009.06.054.

[26] Walker G, Devine-Wright P. Community renewable energy: What should it mean? Energy Policy 2008;36:497-500. doi:10.1016/j.enpol.2007.10.019.

[27] Walker $G$. What are the barriers and incentives for community-owned means of energy production and use? Energy Policy 2008;36:4401-5. doi:10.1016/j.enpol.2008.09.032.

[28] Solar Powering Your Community: A Guide for Local Governments. U.S. Department of Energy; 2011.

[29] John JS. Only Two US Community Solar Developers Have Finished More Than One Project. Why? : Greentech Media 2014. http://www.greentechmedia.com/articles/read/community-solar-a-bigidea-with-big-barriers (accessed July 15, 2014). 
[30] Watson P, Gabriel M, Rooney M. Get bill smart: A community-partnership approach to supporting low-income households to achieve home energy savings. Indoor Built Environ 2015:1420326X15591637. doi:10.1177/1420326X15591637.

[31] Vergragt PJ, Brown HS. The challenge of energy retrofitting the residential housing stock: grassroots innovations and socio-technical system change in Worcester, MA. Technol Anal Amp Strateg Manag 2012;24:407-20. doi:10.1080/09537325.2012.663964.

[32] Müller MO, Stämpfli A, Dold U, Hammer T. Energy autarky: A conceptual framework for sustainable regional development. Energy Policy 2011;39:5800-10. doi:10.1016/j.enpol.2011.04.019.

[33] St. Denis G, Parker P. Community energy planning in Canada: The role of renewable energy. Renew Sustain Energy Rev 2009;13:2088-95. doi:10.1016/j.rser.2008.09.030.

[34] Radtke J. A closer look inside collaborative action: civic engagement and participation in community energy initiatives. People Place Policy 2015;8:235-48. doi:10.3351/ppp.0008.0003.0008.

[35] Huang Z, Yu H, Peng Z, Zhao M. Methods and tools for community energy planning: A review. Renew Sustain Energy Rev 2015;42:1335-48. doi:10.1016/j.rser.2014.11.042.

[36] van der Schoor T, Scholtens B. Power to the people: Local community initiatives and the transition to sustainable energy. Renew Sustain Energy Rev 2015;43:666-75. doi:10.1016/j.rser.2014.10.089.

[37] Smith A, Hargreaves T, Hielscher S, Martiskainen M, Seyfang G. Making the most of community energies: Three perspectives on grassroots innovation. Environ Plan A 2015:0308518X15597908. doi:10.1177/0308518X15597908.

[38] Wiersma B, Devine-Wright P. Decentralising energy: comparing the drivers and influencers of projects led by public, private, community and third sector actors. Contemp Soc Sci 2014;9:45670. doi:10.1080/21582041.2014.981757.

[39] Kaldellis JK, Zafirakis D, Kavadias K. Techno-economic comparison of energy storage systems for island autonomous electrical networks. Renew Sustain Energy Rev 2009;13:378-92. doi:10.1016/j.rser.2007.11.002.

[40] Hicks J, Ison N. Community-owned renewable energy (CRE): Opportunities for rural Australia. Rural Soc 2011;20:244-55. doi:10.5172/rsj.20.3.244.

[41] Gross C. Community perspectives of wind energy in Australia: The application of a justice and community fairness framework to increase social acceptance. Energy Policy 2007;35:2727-36. doi:10.1016/j.enpol.2006.12.013. 
[42] Sánchez AS, Torres EA, Kalid RA. Renewable energy generation for the rural electrification of isolated communities in the Amazon Region. Renew Sustain Energy Rev 2015;49:278-90. doi:10.1016/j.rser.2015.04.075.

[43] Nigim K, Munier N, Green J. Pre-feasibility MCDM tools to aid communities in prioritizing local viable renewable energy sources. Renew Energy 2004;29:1775-91.

doi:10.1016/j.renene.2004.02.012.

[44] Rezaei M, Dowlatabadi H. Off-grid: community energy and the pursuit of self-sufficiency in British Columbia's remote and First Nations communities. Local Environ 2015;0:1-19. doi:10.1080/13549839.2015.1031730.

[45] Alvial-Palavicino C, Garrido-Echeverría N, Jiménez-Estévez G, Reyes L, Palma-Behnke R. A methodology for community engagement in the introduction of renewable based smart microgrid. Energy Sustain Dev 2011;15:314-23. doi:10.1016/j.esd.2011.06.007.

[46] Jenny A, Fuentes FH, Mosler H-J. Psychological Factors Determining Individual Compliance with Rules for Common Pool Resource Management: The Case of a Cuban Community Sharing a Solar Energy System. Hum Ecol 2007;35:239-50. doi:10.1007/s10745-006-9053-x.

[47] Magnoni S, Bassi AM. Creating Synergies from Renewable Energy Investments, a Community Success Story from Lolland, Denmark. Energies 2009;2:1151-69. doi:10.3390/en20401151.

[48] Ranaboldo M, Ferrer-Martí L, García-Villoria A, Pastor Moreno R. Heuristic indicators for the design of community off-grid electrification systems based on multiple renewable energies. Energy 2013;50:501-12. doi:10.1016/j.energy.2012.11.025.

[49] Doukas H, Papadopoulou A, Savvakis N, Tsoutsos T, Psarras J. Assessing energy sustainability of rural communities using Principal Component Analysis. Renew Sustain Energy Rev 2012;16:194957. doi:10.1016/j.rser.2012.01.018.

[50] Raven RPJM, Heiskanen E, Lovio R, Hodson M, Brohmann B. The Contribution of Local Experiments and Negotiation Processes to Field-Level Learning in Emerging (Niche) Technologies Meta-Analysis of 27 New Energy Projects in Europe. Bull Sci Technol Soc 2008;28:464-77. doi:10.1177/0270467608317523.

[51] Bassam N El. Renewable energy for rural communities. Renew Energy 2001;24:401-8. doi:10.1016/S0960-1481(01)00022-2.

[52] Li LW, Birmele J, Schaich H, Konold W. Transitioning to Community-owned Renewable Energy: Lessons from Germany. Procedia Environ Sci 2013;17:719-28. doi:10.1016/j.proenv.2013.02.089.

[53] Schweizer-Ries P. Energy sustainable communities: Environmental psychological investigations. Energy Policy 2008;36:4126-35. doi:10.1016/j.enpol.2008.06.021. 
[54] Dóci G, Vasileiadou E. "Let's do it ourselves" Individual motivations for investing in renewables at community level. Renew Sustain Energy Rev 2015;49:41-50. doi:10.1016/j.rser.2015.04.051.

[55] Neves D, Silva CA, Connors S. Design and implementation of hybrid renewable energy systems on micro-communities: A review on case studies. Renew Sustain Energy Rev 2014;31:935-46. doi:10.1016/j.rser.2013.12.047.

[56] Haralambopoulos DA, Polatidis H. Renewable energy projects: structuring a multi-criteria group decision-making framework. Renew Energy 2003;28:961-73. doi:10.1016/S0960-1481(02)00072-1.

[57] Kanase-Patil AB, Saini RP, Sharma MP. Integrated renewable energy systems for off grid rural electrification of remote area. Renew Energy 2010;35:1342-9. doi:10.1016/j.renene.2009.10.005.

[58] Ashok S. Optimised model for community-based hybrid energy system. Renew Energy 2007;32:1155-64. doi:10.1016/j.renene.2006.04.008.

[59] Wirth S. Communities matter: Institutional preconditions for community renewable energy. Energy Policy 2014;70:236-46. doi:10.1016/j.enpol.2014.03.021.

[60] Maruyama Y, Nishikido M, lida T. The rise of community wind power in Japan: Enhanced acceptance through social innovation. Energy Policy 2007;35:2761-9.

doi:10.1016/j.enpol.2006.12.010.

[61] Zahnd A, Kimber HM. Benefits from a renewable energy village electrification system. Renew Energy 2009;34:362-8. doi:10.1016/j.renene.2008.05.011.

[62] Boon FP. Local is Beautiful: The emergence and development of local renewable energy organisations 2012.

[63] Ferrer-Martí L, Garwood A, Chiroque J, Ramirez B, Marcelo O, Garfí M, et al. Evaluating and comparing three community small-scale wind electrification projects. Renew Sustain Energy Rev 2012;16:5379-90. doi:10.1016/j.rser.2012.04.015.

[64] Duić N, Lerer M, Carvalho MG. Increasing the supply of renewable energy sources in island energy systems. Int J Sustain Energy 2003;23:177-86. doi:10.1080/01425910412331290760.

[65] López González LM, Sala Lizarraga JM, Míguez Tabarés JL, López Ochoa LM. Contribution of renewable energy sources to electricity production in the autonomous community of Navarre (Spain): A review. Renew Sustain Energy Rev 2007;11:1776-93. doi:10.1016/j.rser.2006.01.002.

[66] Hsueh S-L. Assessing the effectiveness of community-promoted environmental protection policy by using a Delphi-fuzzy method: A case study on solar power and plain afforestation in Taiwan. Renew Sustain Energy Rev 2015;49:1286-95. doi:10.1016/j.rser.2015.05.008. 
[67] Promoting Community Renewable Energy in a Corporate Energy World - Strachan - 2015 Sustainable Development - Wiley Online Library n.d.

http://onlinelibrary.wiley.com.prxy4.ursus.maine.edu/doi/10.1002/sd.1576/full (accessed August $19,2015)$.

[68] Parra D, Gillott M, Norman SA, Walker GS. Optimum community energy storage system for PV energy time-shift. Appl Energy 2015;137:576-87. doi:10.1016/j.apenergy.2014.08.060.

[69] Seyfang G, Hielscher S, Hargreaves T, Martiskainen M, Smith A. A grassroots sustainable energy niche? Reflections on community energy in the UK. Environ Innov Soc Transit 2014;13:21-44. doi:10.1016/j.eist.2014.04.004.

[70] Hargreaves T, Hielscher S, Seyfang G, Smith A. Grassroots innovations in community energy: The role of intermediaries in niche development. Glob Environ Change 2013;23:868-80. doi:10.1016/j.gloenvcha.2013.02.008.

[71] Parag Y, Hamilton J, White V, Hogan B. Network approach for local and community governance of energy: The case of Oxfordshire. Energy Policy 2013;62:1064-77. doi:10.1016/j.enpol.2013.06.027.

[72] Seyfang G, Park JJ, Smith A. A thousand flowers blooming? An examination of community energy in the UK. Energy Policy 2013;61:977-89. doi:10.1016/j.enpol.2013.06.030.

[73] Saunders RW, Gross RJK, Wade J. Can premium tariffs for micro-generation and small scale renewable heat help the fuel poor, and if so, how? Case studies of innovative finance for community energy schemes in the UK. Energy Policy 2012;42:78-88. doi:10.1016/j.enpol.2011.11.045.

[74] Allen J, Sheate WR, Diaz-Chavez R. Community-based renewable energy in the Lake District National Park - local drivers, enablers, barriers and solutions. Local Environ 2012;17:261-80. doi:10.1080/13549839.2012.665855.

[75] Gormally AM, Whyatt JD, Timmis RJ, Pooley CG. A regional-scale assessment of local renewable energy resources in Cumbria, UK. Energy Policy 2012;50:283-93. doi:10.1016/j.enpol.2012.07.015.

[76] Rogers JC, Simmons EA, Convery I, Weatherall A. Social impacts of community renewable energy projects: findings from a woodfuel case study. Energy Policy 2012;42:239-47. doi:10.1016/j.enpol.2011.11.081.

[77] Rogers JC, Simmons EA, Convery I, Weatherall A. What factors enable community leadership of renewable energy projects? Lessons from a woodfuel heating initiative. Local Econ 2012;27:20922. doi:10.1177/0269094211429657.

[78] Walker G, Devine-Wright P, Hunter S, High H, Evans B. Trust and community: Exploring the meanings, contexts and dynamics of community renewable energy. Energy Policy 2010;38:265563. doi:10.1016/j.enpol.2009.05.055. 
[79] Walker G. Decentralised systems and fuel poverty: Are there any links or risks? Energy Policy 2008;36:4514-7. doi:10.1016/j.enpol.2008.09.020.

[80] Rogers JC, Simmons EA, Convery I, Weatherall A. Public perceptions of opportunities for community-based renewable energy projects. Energy Policy 2008;36:4217-26. doi:10.1016/j.enpol.2008.07.028.

[81] van der Horst D. Social enterprise and renewable energy: emerging initiatives and communities of practice. Soc Enterp J 2008;4:171-85. doi:10.1108/17508610810922686.

[82] Walker G, Cass N. Carbon reduction, "the public" and renewable energy: engaging with sociotechnical configurations. Area 2007;39:458-69. doi:10.1111/j.1475-4762.2007.00772.x.

[83] Walker G, Hunter S, Devine-Wright P, Evans B, Fay H. Harnessing Community Energies: Explaining and Evaluating Community-Based Localism in Renewable Energy Policy in the UK. Glob Environ Polit 2007;7:64-82. doi:10.1162/glep.2007.7.2.64.

[84] Burton J, Hubacek K. Is small beautiful? A multicriteria assessment of small-scale energy technology applications in local governments. Energy Policy 2007;35:6402-12. doi:10.1016/j.enpol.2007.08.002.

[85] Leaney, V. Leaney, Jenkins, D. Jenkins, Rowlands, A. Rowlands, et al. Local and community ownership of renewable energy power production: Examples of wind turbine projects. Wind Eng 2001;25:215-26. doi:10.1260/0309524011496033.

[86] Coles A-M, Piterou A, Genus A. Sustainable energy projects and the community: Mapping singlebuilding use of microgeneration technologies in London. Urban Stud 2015:0042098015581575. doi:10.1177/0042098015581575.

[87] Armstrong A, Bulkeley H. Micro-hydro politics: Producing and contesting community energy in the North of England. Geoforum 2014;56:66-76. doi:10.1016/j.geoforum.2014.06.015.

[88] Okkonen L, Lehtonen O. Socio-economic impacts of community wind power projects in Northern Scotland. Renew Energy 2016;85:826-33. doi:10.1016/j.renene.2015.07.047.

[89] Haggett C, Aitken M. Grassroots Energy Innovations: the Role of Community Ownership and Investment. Curr Sustain Energy Rep 2015:1-7. doi:10.1007/s40518-015-0035-8.

[90] Slee B. Is there a case for community-based equity participation in Scottish on-shore wind energy production? Gaps in evidence and research needs. Renew Sustain Energy Rev 2015;41:540-9. doi:10.1016/j.rser.2014.08.064.

[91] Bomberg E, McEwen N. Mobilizing community energy. Energy Policy 2012;51:435-44. doi:10.1016/j.enpol.2012.08.045. 
[92] Warren CR, McFadyen M. Does community ownership affect public attitudes to wind energy? A case study from south-west Scotland. Land Use Policy 2010;27:204-13.

doi:10.1016/j.landusepol.2008.12.010.

[93] Harnmeijer J, Harnmeijer A, Loyd C. TOWARDS A GLOBAL DATABASE OF COMMUNITY-LED RENEWABLE ENERGY DEVELOPMENT. Reg Mag 2012;287:16-8.

doi:10.1080/13673882.2012.10554276.

[94] Jeong Y, Simcock N, Walker G. Chapter 6 Making Power Differently: Exploring the Motives and Meanings of Community Renewable Energy Development in Cases from the UK and South Korea. Adv Ecopolitics 2012;9:105-21. doi:10.1108/S2041-806X(2012)0000009009.

[95] Noll D, Dawes C, Rai V. Solar Community Organizations and active peer effects in the adoption of residential PV. Energy Policy 2014;67:330-43. doi:10.1016/j.enpol.2013.12.050.

[96] Booth S. Here Come the Sun: How Securities Regulations Case a Shadow on the Growth of Community Solar in the United States. UCLA Law Rev 2013;61:760.

[97] Read A. Solar America Communities. Public Manag 00333611 2011;93:24-5.

[98] Bolinger MA. Making European-style community wind power development work in the US. Renew Sustain Energy Rev 2005;9:556-75. doi:10.1016/j.rser.2004.04.002.

[99] Yin Y. An analysis of empirical cases of community wind in Oregon. Renew Sustain Energy Rev 2013;17:54-73. doi:10.1016/j.rser.2012.09.020.

[100] Van Hoesen J, Letendre S. Evaluating potential renewable energy resources in Poultney, Vermont: A GIS-based approach to supporting rural community energy planning. Renew Energy 2010;35:2114-22. doi:10.1016/j.renene.2010.01.018.

[101] Vermont Energy \& Climate Action Network 2014. http://www.vecan.net/about/ (accessed June 10, 2014).

[102] Funk CL. Practicing What We Preach? The Influence of a Societal Interest Value on Civic Engagement. Polit Psychol 1998;19:601-14. doi:10.1111/0162-895X.00120.

[103] Stewart MC. Voice and Equality: Civic Voluntarism in American Politics Sidney Verba, Kay Lehman Schlozman and Henry E. Brady Cambridge: Harvard University Press, 1995, pp. xix, 640. Can J Polit Sci Can Sci Polit 1997;30:380-1. doi:10.1017/S000842390001564X.

[104] Robert D. Putnam. Bowling Alone: the Collapse and Revival of American Community. New York, NY: Touchstone; 2000. 
[105] David Feldman, Anna Brockway, Elaine Ulrich, Robert Margolis. Shared Solar: current landscape, market potential, and the impact of federal securities regulation. Golden, CO: National Renewable Energy Laboratory; 2015.

[106] U.S. Department of Energy. SunShot Initiative Information Resources 2014. http://www4.eere.energy.gov/solar/sunshot/resource_center/filter?topic[0]=25\&\&\&state=All (accessed June 6, 2014).

[107] Linda Irvine, Alexandra Sawyer, Jennifer Grove. The Solarize Guidebook: A community guide to collective purchasing of residential PV systems 2012.

[108] Energy Archipelago 2014. http://beta.energyarchipelago.com/\# (accessed December 5, 2014).

[109] Transition Initiatives Directory. Transit Netw 2013. http://www.transitionnetwork.org/initiatives (accessed October 15, 2014).

[110] US EPA O. Local Climate and Energy Program | State and Local | US EPA n.d. http://www.epa.gov/statelocalclimate/local/index.html (accessed December 18, 2014).

[111] US EPA O. Case Studies | State and Local | US EPA n.d. http://www.epa.gov/statelocalclimate/state/state-examples/case-studies.html\#all (accessed December 18, 2014).

[112] Vermont Energy \& Climate Action Network (VECAN) 2014. http://www.vecan.net/ (accessed July 18, 2014).

[113] Miller J, Klein S. Personal communication 2014.

[114] trudeau I. Large Wind. Minn Dep Commer n.d. http://mn.gov/commerce/energy/consumers/Wind-Systems/Large-Wind-Systems.jsp (accessed December 18, 2014).

[115] National Solar Schools Census | The Solar Foundation 2012. http://www.thesolarfoundation.org/education/national-solar-schools-census (accessed December $18,2014)$.

[116] Solarize Mass n.d. http://www.masscec.com/solarizemass (accessed December 18, 2014).

[117] NREL. The Open PV Project n.d. https://openpv.nrel.gov/ (accessed December 10, 2014).

[118] John Farrell. Community Solar Power Obstacles and Opportunities. The New Rules Project; 2010.

[119] CEC. Clean Energy Collective 2014. http://www.easycleanenergy.com/communitysolarprojects.aspx (accessed December 13, 2014). 
[120] US Small Business Administration. Limited Liability Company n.d. https://www.sba.gov/content/limited-liability-company-Ilc (accessed December 13, 2014).

[121] Database of state incentives for renewables \& efficiency. DSIRE USA n.d. http://dsireusa.org/incentives/incentive.cfm (accessed July 18, 2014).

[122] Tired of Waiting for the SEC, States Adopt Their Own Crowdfunding Rules. Ice Mill LLP n.d. http://www.icemiller.com/Ice-on-Fire-Insights/Publications/Tired-of-Waiting-for-the-SEC,-StatesAdopt-Their-W (accessed December 18, 2014).

[123] American Wind Energy Association. Community Wind Projects Database 2014. http://www.awea.org/Issues/Content.aspx?ItemNumber=5323.

[124] Illinois State University Center for Renewable Energy. Illinois Wind Power Projects 2014. http://renewableenergy.illinoisstate.edu/wind/databases.shtml (accessed November 20, 2014).

[125] Jason Coughlin, Jennifer Grove, Linda Irvine, Janet F. Jacobs, Sarah Johnson Phillips, Leslie Moynihan, et al. A guide to community solar: utility, private, and non-profit project development. NREL; 2011.

[126] Neighborhood Solar Bulk Purchases. DC SUN n.d. http://www.dcsun.org/bulk-purchases/ (accessed December 18, 2014).

[127] Speer B. The New(er) Kids on the Block: Community Choice Aggregators 2011.

[128] U.S. Department of Energy. Green Power Markets. Green Pricing Util Programs State 2014. http://apps3.eere.energy.gov/greenpower/markets/pricing.shtml?page=1 (accessed December 15, 2014).

[129] U.S. Department of Energy. High Performance Builder Spotlight: Clarum Homes, Watsonville, Callifornia n.d.

[130] Home. Geos Neighborhood n.d. http://discovergeos.com/ (accessed December 18, 2014).

[131] Fellowship for Intentional Community n.d. http://www.ic.org/directory/search/ (accessed December 18, 2014).

[132] Cardwell D. Buying Into Solar Power, No Roof Access Needed. N Y Times 2014. 
Table 1 - Summary of Community Energy Literature

\begin{tabular}{|c|c|c|c|}
\hline Geographic Region & Energy Option & Year of Publication & Citation \\
\hline Australia & efficiency, conservation & 2015 & [30] \\
\hline UK & efficiency, conservation & 2012 & [23] \\
\hline US - Massachusetts & efficiency, conservation & 2012 & [31] \\
\hline $\begin{array}{l}\text { Austria, Germany, } \\
\text { Switzerland }\end{array}$ & renewable, efficiency, conservation & 2011 & [32] \\
\hline Canada & renewable, efficiency, conservation & 2009 & [33] \\
\hline $\begin{array}{l}\text { Denmark, Austria, } \\
\text { Switzerland }\end{array}$ & $\begin{array}{l}\text { renewable (solar, wind), efficiency, } \\
\text { conservation }\end{array}$ & 2013 & [17] \\
\hline Germany & $\begin{array}{l}\text { renewable (wind), efficiency, } \\
\text { conservation }\end{array}$ & 2015 & [34] \\
\hline Global & renewable, efficiency, conservation & 2015 & [35] \\
\hline Netherlands & $\begin{array}{l}\text { renewable (biomass, solar, hydro), } \\
\text { efficiency }\end{array}$ & 2015 & [36] \\
\hline US - Minnesota & renewable, efficiency, conservation & 2010 & [25] \\
\hline UK & renewable, efficiency, conservation & 2015 & [37] \\
\hline UK & renewable (biomass, solar), efficiency & 2014 & [38] \\
\hline $\begin{array}{l}\text { Aegean Archipelago } \\
\text { Islands }\end{array}$ & renewable, storage & 2009 & [39] \\
\hline Australia & renewable & 2011 & [40] \\
\hline Australia & renewable (wind) & 2007 & [41] \\
\hline Brazil - Amazon & renewable & 2015 & [42] \\
\hline Canada & renewable & 2004 & [43] \\
\hline $\begin{array}{l}\text { Canada - BC First } \\
\text { Nations }\end{array}$ & renewable & 2015 & [44] \\
\hline Chile & renewable & 2011 & [45] \\
\hline Cuba & renewable (solar) & 2006 & [46] \\
\hline $\begin{array}{l}\text { Denmark - Lolland } \\
\text { island }\end{array}$ & renewable & 2009 & [47] \\
\hline developing nations & renewable & 2013 & [48] \\
\hline Europe & renewable & 2012 & [49] \\
\hline Europe & renewable (biomass) & 2008 & [50] \\
\hline Europe & renewable & 2001 & [51] \\
\hline Germany & renewable & 2013 & [52] \\
\hline Germany & renewable & 2008 & [53] \\
\hline Germany, Netherlands & renewable & 2015 & [54] \\
\hline Global & renewable (solar), storage & 2014 & [55] \\
\hline Greece & renewable (geothermal) & 2003 & {$[56]$} \\
\hline India & $\begin{array}{l}\text { renewable (biomass, hydro, solar, } \\
\text { wind) }\end{array}$ & 2010 & [57] \\
\hline India & $\begin{array}{l}\text { renewable (hydro, solar, wind), } \\
\text { storage }\end{array}$ & 2007 & [58] \\
\hline Italy & renewable (biomass) & 2014 & [59] \\
\hline
\end{tabular}




\begin{tabular}{|c|c|c|c|}
\hline Japan & renewable (wind) & 2007 & [60] \\
\hline Nepal & renewable (hydro, solar) & 2009 & [61] \\
\hline Netherlands & renewable & 2012 & [62] \\
\hline Peru & renewable (solar, wind) & 2012 & [63] \\
\hline $\begin{array}{l}\text { Porto Santo - island in } \\
\text { Madeira archipelago }\end{array}$ & $\begin{array}{l}\text { renewable (solar, wind), hydrogen } \\
\text { storage }\end{array}$ & 2003 & [64] \\
\hline Spain & $\begin{array}{l}\text { renewable (biomass, hydro, solar, } \\
\text { wind) }\end{array}$ & 2007 & [65] \\
\hline Taiwan & renewable (solar) & 2015 & [66] \\
\hline UK & renewable & 2015 & [67] \\
\hline UK & storage & 2015 & [68] \\
\hline UK & renewable & 2014 & [69] \\
\hline UK & renewable & 2013 & [70] \\
\hline UK & renewable & 2013 & [71] \\
\hline UK & $\begin{array}{l}\text { renewable (biomass, geothermal, } \\
\text { hydro, solar, tidal, wave, wind) }\end{array}$ & 2013 & [72] \\
\hline UK & renewable & 2012 & [73] \\
\hline UK & renewable & 2012 & [74] \\
\hline UK & $\begin{array}{l}\text { renewable (biomass, hydro, solar, } \\
\text { wind) }\end{array}$ & 2012 & [75] \\
\hline UK & renewable (biomass) & 2012 & [76] \\
\hline UK & renewable (biomass) & 2012 & [77] \\
\hline UK & renewable & 2010 & [78] \\
\hline UK & renewable & 2008 & [79] \\
\hline UK & renewable & 2008 & [80] \\
\hline UK & renewable & 2008 & [81] \\
\hline UK & renewable & 2008 & [27] \\
\hline UK & renewable & 2007 & [82] \\
\hline UK & renewable & 2007 & [26] \\
\hline UK & renewable & 2007 & [83] \\
\hline UK & renewable & 2007 & [84] \\
\hline UK & renewable (wind) & 2001 & [85] \\
\hline UK - England & renewable & 2015 & [86] \\
\hline UK - England & renewble (hydro) & 2014 & [87] \\
\hline UK - Scotland & renewable (wind) & 2016 & [88] \\
\hline UK - Scotland & renewable & 2015 & [89] \\
\hline UK - Scotland & renewable (wind) & 2015 & [90] \\
\hline UK - Scotland & renewable & 2012 & [91] \\
\hline UK - Scotland & renewable (wind) & 2010 & [92] \\
\hline UK - Scotland & renewable & 2012 & [93] \\
\hline UK, South Korea & renewable & 2012 & [94] \\
\hline US & renewable (solar) & 2014 & [95] \\
\hline US & renewable (solar) & 2013 & [96] \\
\hline
\end{tabular}




\begin{tabular}{|c|c|c|c|}
\hline US & renewable (solar) & 2011 & [97] \\
\hline US & renewable (wind) & 2005 & [98] \\
\hline US - Oregon & renewable (wind) & 2013 & [99] \\
\hline US - Vermont & renewable (biomass, solar, wind) & 2010 & [100] \\
\hline
\end{tabular}


Table 2 - Community Renewable Energy Classification System ${ }^{\mathrm{a}}$

\begin{tabular}{|c|c|c|c|c|c|c|c|c|c|c|c|}
\hline$\#$ & $\begin{array}{c}\text { Financial Model } \\
\text { Name }\end{array}$ & Financial Model Description & $\begin{array}{l}\text { "Community" } \\
\text { Definition }\end{array}$ & $\bar{A}$ & $\mathbf{B}$ & C & $\mathbf{D}$ & & $\overline{\mathbf{F ~ G}}$ & $H$ & $T$ \\
\hline 1 & $\begin{array}{l}\text { Buying Group } 1 \text { - } \\
\text { Installation }\end{array}$ & $\begin{array}{l}\text { Individuals form a group to take advantage of reduced RE } \\
\text { installation costs through bulk purchasing from a single } \\
\text { supplier or a set of pre-approved competitors; Individuals } \\
\text { pay for their own installations through private funds and/or } \\
\text { loans; Examples: Solarize [37], RE Cooperatives [50,59] }\end{array}$ & $\begin{array}{l}\text { Members of the } \\
\text { buying group }\end{array}$ & 1 & 1 & 1 & 1 & 1 & 11 & $\mathrm{H}$ & $\mathrm{L}-\mathrm{H}$ \\
\hline 2 & $\begin{array}{l}\text { Buying Group } 2 \text { - } \\
\text { Electricity }\end{array}$ & $\begin{array}{l}\text { Municipalities form public agencies to buy RE generation } \\
\text { for their residents, allowing residents to opt-in or -out of } \\
\text { RE power purchase; the buying group may select a single } \\
\text { supplier or allow customers to choose between a pre- } \\
\text { approved set of competitors; Examples: Community } \\
\text { Choice Aggregation [60], Green Pricing [61] }\end{array}$ & $\begin{array}{l}\text { Members of the } \\
\text { buying group }\end{array}$ & $2,1^{b}$ & 2 & 2 & 2 & 2 & & L-M & L \\
\hline 3 & $\begin{array}{l}\text { Green Planned } \\
\text { Housing } \\
\text { Development }\end{array}$ & $\begin{array}{l}\text { An external investor/contractor constructs a housing } \\
\text { development or planned community with attention to } \\
\text { green building practices, which may include CRE3 } \\
\text { options, and sells it to individual homebuyers; Examples: } \\
\text { Clarum Homes [62]; Geos Neighborhood [63] }\end{array}$ & $\begin{array}{l}\text { Residents of } \\
\text { development }\end{array}$ & 2 & 1 & 1 & 1 & 2 & 11 & $\begin{array}{c}\mathrm{M}- \\
\mathrm{H}\end{array}$ & L-H \\
\hline 4 & $\begin{array}{l}\text { Intentional } \\
\text { Sustainable } \\
\text { Communities }\end{array}$ & $\begin{array}{l}\text { A group of people with similar morals, ethics, and/or } \\
\text { beliefs choose to live in the same geographic area and } \\
\text { agree on a set of guiding principles related to } \\
\text { sustainability, including adopting renewable energy; } \\
\text { Examples: Elemental Eden and others listed by The } \\
\text { Fellowship for Intentional Community [64] }\end{array}$ & $\begin{array}{l}\text { Residents of } \\
\text { development }\end{array}$ & 1 & 1 & 1 & 1 & 1 & 11 & $\mathrm{H}$ & $\mathrm{H}$ \\
\hline 5 & One-Time Funds & $\begin{array}{l}\text { An entity installs a RE system using tax revenues, } \\
\text { donations/grant money, or other internal funds; Examples: } \\
\text { RE installation on government property (Ellensburg [50]), } \\
\text { school (Solar for Sakai [50]), college, university, church, } \\
\text { other non-profit, cooperative utilities or cooperative } \\
\text { businesses }\end{array}$ & $\begin{array}{l}\text { Members of the } \\
\text { entity that } \\
\text { installed the } \\
\text { system }\end{array}$ & 1 & 1 & 1 & 1 & 1 & 11 & $\mathrm{H}$ & $\mathrm{H}$ \\
\hline 6 & PPA & $\begin{array}{l}\text { Power purchase agreement; a developer (usually a LLC) } \\
\text { created specifically for this purpose or a private or public } \\
\text { utility) owns, operates, and maintains the RE system on } \\
\text { its own property or on the property of a host organization } \\
\text { (usually a non-profit organization) and sells electricity } \\
\text { generated from the RE system to customers (usually the } \\
\text { host organization or utility customers) for a specified } \\
\text { period of time (often } 20-25 \text { yrs); Often referred to as Solar } \\
\text { Gardens; Examples: University Park Solar [50] }\end{array}$ & $\begin{array}{l}\text { Utility customers } \\
\text { or members of } \\
\text { host } \\
\text { organization } \\
\text { engaged in PPA } \\
\end{array}$ & 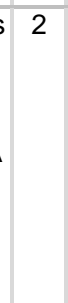 & $1,2^{\mathrm{c}}$ & 2 & 2 & 2 & & $2 \mathrm{~L}-\mathrm{H}$ & L-H \\
\hline 7 & PPA lease & $\begin{array}{l}\text { Same as PPA, but at the end of the PPA, the host } \\
\text { customer has the option to buy the system at the } \\
\text { depreciated values; Often referred to as Solar Gardens; } \\
\text { Example: United Power Sol Partners; FKEC, City of } \\
\text { Ashland Solar Pioneer [50] }\end{array}$ & Same as PPA & 2 & $1,2^{\mathrm{C}}$ & $2,1^{d}$ & $2,1^{d}$ & 2 & & $2 \mathrm{~L}-\mathrm{H}$ & L-H \\
\hline 8 & Shared Ownership & $\begin{array}{l}\text { A developer (usually a LLC, corporation, private or public } \\
\text { utility) constructs a RE installation and then sells it in } \\
\text { blocks to people who live in the vicinity of the installation } \\
\text { or who are customers of the same utility; Often referred to } \\
\text { as Solar Gardens; Example: City of St. George } \\
\text { Sunsmart; Mid Valley Solar CEC [50,51] }\end{array}$ & $\begin{array}{l}\text { People who buy } \\
\text { blocks of RE }\end{array}$ & 2 & 2 & 1 & 2 & 2 & 1 & L-H & L-H \\
\hline $\begin{array}{l}A \\
A \\
B= \\
C \\
D \\
E= \\
F= \\
G= \\
H= \\
I= \\
L= \\
M \\
1=\end{array}$ & $\begin{array}{l}\text { pays annual maint } \\
\text { receives upfront fin } \\
\text { receives energy co } \\
\text { receives tradable } \\
\text { level of individual i } \\
\text { level of community } \\
\text { low } \\
\text { moderate } \\
\text { community membe }\end{array}$ & $\begin{array}{l}\text { tallation } \\
\text { ere the installation is physically located) } \\
\text { nstallation } \\
\text { nance on installation } \\
\text { incial incentive if applicable (i.e., investment tax credit, re } \\
\text { t savings, including annual financial incentive if available } \\
\text { newable energy credits if available; } \\
\text { volvement required/expected; also refers to High in colum } \\
\text { teraction required/expected } \\
\text { as defined in table } \\
\text { nal to community) }\end{array}$ & $\begin{array}{l}\text { ste, grant) } \\
\text { e., production to } \\
\text { S and I }\end{array}$ & & & & & & & & \\
\hline
\end{tabular}


${ }^{\mathrm{b}}$ Customers may be required to pay a surcharge or other upfront fee to be included in the CCA

${ }^{\mathrm{C}}$ The initial investor may host the array (i.e., utility) or the community may host it (i.e., school or church; in this case, it is often known as third party financing/ownership), depending on the specific arrangements of the PPA.

${ }^{\mathrm{d}}$ The initial investor owns the system for a specific agree-upon period of time (usually until the initial investor has captured all policy incentives and the community has paid off any debt incurred), and then depending on the terms of the PPA, ownership may transfer to the community members. 